\title{
Bacterial degradation of dissolved organic matter released by Planktothrix agardhii (Cyanobacteria)
}

\author{
L. P. Tessarolli ${ }^{*}$, I. L. Bagatini ${ }^{a}$, I. Bianchini-Jr. ${ }^{b}$ and A. A. H. Vieira \\ a'Laboratório de Ficologia, Departamento de Botânica, Universidade Federal de São Carlos - UFSCar, \\ Via Washington Luís, Km 235, CEP 13565-905, São Carlos, SP, Brazil \\ ${ }^{b}$ Laboratório de Limnologia e Modelagem Matemática, Departamento de Hidrobiologia, Universidade Federal de São \\ Carlos - UFSCar, Via Washington Luís, Km 235, CEP 13565-905, São Carlos, SP, Brazil \\ *e-mail: letessarolli@gmail.com
}

Received: May 25, 2016 - Accepted: August 23, 2016 - Distributed: February 28, 2018

(With 2 figures)

\begin{abstract}
Although Planktothrix agardhii often produces toxic blooms in eutrophic water bodies around the world, little is known about the fate of the organic matter released by these abundant Cyanobacteria. Thus, this study focused in estimating the bacterial consumption of the DOC and DON (dissolved organic carbon and dissolved organic nitrogen, respectively) produced by axenic $P$. agardhii cultures and identifying some of the bacterial OTUs (operational taxonomic units) involved in the process. Both P. agardhii and bacterial inocula were sampled from the eutrophic Barra Bonita Reservoir (SP, Brazil). Two distinct carbon degradation phases were observed: during the first three days, higher degradation coefficients were calculated, which were followed by a slower degradation phase. The maximum value observed for particulate bacterial carbon (POC) was $11.9 \mathrm{mg} \mathrm{L}^{-1}$, which consisted of $62.5 \%$ of the total available DOC, and its mineralization coefficient was 0.477 day $^{-1}\left(\mathrm{t}^{1} / 2=1.45\right.$ days $)$. A similar pattern of degradation was observed for DON, although the coefficients were slightly different. Changes in the OTUs patterns were observed during the different steps of the degradation. The main OTUs were related to the classes Alphaproteobacteria (8 OTUs), Betaproteobacteria (2 OTUs) and Gammaproteobacteria (3 OTUs). The genus Acinetobacter was the only identified organism that occurred during the whole process. Bacterial richness was higher at the slower degradation phase, which could be related to the small amounts of DOM (dissolved organic matter) available, particularly carbon. The kinetics of the bacterial degradation of $P$. agardhii-originated DOM suggests minimal loss of DOM from the Barra Bonita reservoir.
\end{abstract}

Keywords: dissolved organic matter, bacterial community, DGGE, degradation.

\section{Degradação bacteriana da matéria orgânica dissolvida liberada por Planktothrix agardhii (Cyanobacteria)}

\begin{abstract}
Resumo
Embora Planktothrix agardhii frequentemente forme florações tóxicas em corpos d'água pelo mundo, pouco ainda se sabe sobre o destino da matéria orgânica liberada por essa abundante Cyanobacteria. Assim, este estudo foi focado na estimativa do consumo bacteriano do carbono orgânico dissolvido (DOC) e nitrogênio orgânico dissolvido (DON) produzido por culturas axênicas de $P$. agardhii e identificação de algumas das unidades taxonômicas operacionais (OTUs) bacterianas envolvidas no processo. Ambos a linhagem de $P$. agardhii e o inóculo bacteriano foram amostrados do reservatório eutrófico de Barra Bonita (SP, Brasil). Foram observadas duas fases distintas da degradação do DOC: durante os três primeiros dias, coeficientes mais altos de degradação foram calculados, que foram então seguidos por uma fase mais lenta da degradação do carbono. O valor máximo calculado para o carbono bacteriano particulado (POC) foi de $11,9 \mathrm{mgL}^{-1}$, o que equivale a aproximadamente $62,5 \%$ do DOC disponível para consumo, e o seu coeficiente de mineralização foi de 0,477 dia $^{-1}\left(\mathrm{t}_{1 / 2}=1,45\right.$ dias $)$. Um padrão similar de degradação foi observado para DON, embora os coeficientes sejam ligeiramente diferentes. Foram observadas mudanças nos padrões de OTUs durante os diferentes passos da degradação. As principais OTUs foram relacionadas às classes Alphaproteobacteria (8 OTUs), Betaproteobacteria (2 OTUs) e Gammaproteobacteria (3 OTUs). O gênero Acinetobacter foi o único organismo identificado que ocorreu durante todo o processo. A maior riqueza bacteriana foi observada durante a fase lenta de degradação, o que pode estar relacionado às pequenas quantidades de matéria orgânica dissovida (DOM) disponíveis, particularmente o carbono. A cinética da degradação bacteriana da MOD de P. agardhii, quando comparada ao tempo de retenção do reservatório, sugere que existe uma perda mínima após sua liberação em Barra Bonita.
\end{abstract}

Palavras-chave: matéria orgânica dissolvida, comunidade bacteriana, DGGE, degradação. 


\section{Introduction}

Planktothrix agardhii frequently forms large perennial metalimnion populations in shallow eutrophic reservoirs around the world (Bonilla et al., 2012). It is responsible for the production of large quantities of particulate organic carbon (Kokociński et al., 2010), and also release large quantities of dissolved organic carbon (DOC) naturally by health cells (Dellamano-Oliveira et al., 2007). The dissolved organic matter (DOM) released by phytoplankton is a recognized source of high quality organic carbon for heterotrophic organisms, mainly bacterial populations (Giroldo et al., 2007; Sarmento and Gasol, 2012). In general, the DOM released by phytoplankton is swiftly consumed and remineralized by the bacterial community and the degradation process allows the reintroduction of compounds in the trophic net, reinstating their availability to higher trophic levels (Azam et al., 1994; Thomas, 1997), and thus, avoiding the loss of compounds, which could otherwise reach the bottom of the reservoir or be exported downstream. There are many studies about cyanotoxins degradation, including microcystins produced by P. agardhii (Chen et al., 2008; Kormas and Lymperopoulou, 2013). However, besides its importance as a biomass producer and potentially toxic products (Briand et al., 2008; Tonk et al., 2005), almost no data can be found on the destination of DOC and how this process may affect the establishment and maintenance of the local bacterial community.

Many factors which directly affect the carbon flux and the interactions between phytoplankton and associated bacterial community act simultaneously and may hinder the acquisition of data for elaborated studies. For example, the DOM composition released by a phytoplankton species may vary with cells age (Myklestad et al., 1989), the degradation rate can be affected by the local climate conditions (Ho et al., 2012; Oberhaus et al., 2007) and by the bacterial community composition (Jones et al., 2009). Thus, in vitro tests, under controlled conditions, are starting points for understanding the interactions between different factors.

In our study, we postulated that most of the DOM released in axenic cultures is due to obligatory metabolism processes of the phytoplankton species and thus, would also be released at the natural environment, before any chemical or biological degradation such as the attack of bacteria or other organisms. The quality and availability of compounds in these released DOM and the presence of specialists and generalists bacterial groups will influence the bacterial community composition during the degradation process (Allen et al., 2005; Davidson et al., 2007; Giroldo et al., 2007). Therefore, we focused on trying to estimate the fate of dissolved organic carbon and nitrogen released by axenic cultures of $P$. agardhii under bacterial degradation, and simultaneously determine the main bacterial OTUs (Operational taxonomic units) involved in the process.

\section{Material and Methods}

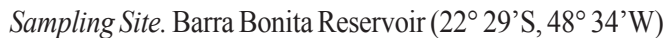
is a eutrophic polymitic and shallow (average depth of $10 \mathrm{~m}$ and $\max 30 \mathrm{~m}$ ) reservoir, located at the Tietê River basin, central São Paulo State, Brazil. It spreads for an area of $310 \mathrm{~km}^{2}$ with total volume of $3.2 \mathrm{~km}^{3}$ and is situated $480 \mathrm{~m}$ over sea level. During summer (wet season), the flow is $1500 \mathrm{~m}^{3} / \mathrm{s}$ and average retention time is 37 days, and, during winter (dry season) average values are $200 \mathrm{~m}^{3} / \mathrm{s}$ and 137 days (Matsumura-Tundisi and Tundisi, 2005). However, these characteristics can be strongly influenced by the hydroelectric power plant operability.

\subsection{Organisms and growth conditions}

The Cyanobacteria Planktothrix agardhii (Gomont) Anagostidis et Komárek was isolated from the Barra Bonita Reservoir and maintained in axenic culture (strain BB013) at the Freshwater Microalgae Collection Culture (WDCM 835). Cultures were grown in modified ASM-1 medium (Gorham et al., 1964), $\mathrm{pH} 7.8$, with reduced nitrate availability $\left(28.4 \mathrm{mgL}^{-1}\right)$, which was still high enough to not affect the growth curve (data not shown). Growth conditions were: light irradiance of $80-100 \mu \mathrm{mol} \cdot \mathrm{m}^{-2} \cdot \mathrm{s}^{-1}$ (Quantameter QSL-100, Biospherical Instruments, San Diego, CA, USA), with 12:12 hour (light:dark) cycle, temperature of $23 \pm 1{ }^{\circ} \mathrm{C}$, and the culture was constantly mixed by a magnetic stirrer.

Bacterial Inoculum. We collected the bacterioplankton from Barra Bonita Reservoir using a sterile system as described by (Bagatini et al., 2014). After two hours, the sample was filtered through $1.2 \mu \mathrm{m}$ glass fiber (GF/C - Whatman), under aseptic conditions, for the removal of algae, protozoa and other detritus. To avoid development of eukaryotic organisms during the experiment, bacterial inoculums were treated with cycloheximide (Sigma-Aldrich) (Bagatini et al., 2014) for $12 \mathrm{~h}$ in concentration of $10 \mathrm{mg} \mathrm{L}^{-1}$. The final concentration of this antibiotic in the final assembly of the experiment was lower enough $\left(0.5 \mathrm{mg} \mathrm{L}^{-1}\right)$ to avoid any further influence in the results.

DOM Separation. We obtained the organic matter from $P$. agardhii cultures at the end of exponential phase (21 days). Cells were separated by tangential filtration in hollow fiber cartridge (Xampler ${ }^{\mathrm{TM}}$, AG Technology Corporation/GE, UK) with $0.65 \mu \mathrm{m}$ pores (CFP-6-D-4A), and all the equipment previously sterilized to avoid bacterial contamination. The integrity of the algal cells during separation was verified by the absence of pigments in the filtrate. In sequence, the organic matter $(<0.65 \mu \mathrm{m})$ was filtered through $0.22 \mu \mathrm{m}$ sterile polycarbonate membranes (Millipore, Billerica, MA, USA), further eliminating eventual contaminants. We defined DOM as the fraction smaller than $0.22 \mu \mathrm{m}$.

Bacterial utilization of DOM released by $P$. agardhii. We assembled three experimental cultures (replicates), each containing a final volume of $525 \mathrm{~mL}$ : $500 \mathrm{~mL}$ of DOM (20.907 mg.L $\mathrm{L}^{-1}$ of organic carbon and $2.003 \mathrm{mg} . \mathrm{L}^{-1}$ of dissolved organic nitrogen) and $25 \mathrm{~mL}$ of bacterial inoculum ( $4.8 \%$ of the final volume), which were maintained in the 
dark at $23 \pm 1{ }^{\circ} \mathrm{C}$ to avoid the development of prokaryotic photoautotrophs, and mixed twice a day to avoid anoxia. Cultures were sampled after $0,1,2,3,5,9,12$ and 15 days for the analysis of carbon and nitrogen.

Dissolved organic carbon (DOC) and total nitrogen (TN) were measured with an organic carbon analyzer TOC-Vcph (Shimadzu, Kyoto, Japan) equipped with nitrogen module (TNM-1). All samples were filtered through $0.22 \mu \mathrm{m}$ membranes and both total and dissolved fractions were analyzed. We estimated the particulate fraction as the difference between the total sample and the dissolved fraction $(<0.22 \mu \mathrm{m})$.

We obtained the concentration of dissolved organic nitrogen (DON) indirectly, as the difference between TN (total dissolved nitrogen) and the inorganic fraction (DIN): $\mathrm{DON}=\mathrm{TN}-\mathrm{DIN}$. Analysis of DIN were performed as described by Mackereth et al. (1978) and Solórzano (1969), for nitrate + nitrite and ammonium, respectively $\left(\mathrm{DIN}=\mathrm{NO}_{3}+\mathrm{NO}_{2}+\mathrm{NH}_{4}\right)$.

Kinetic Model. We adjusted the results from organic carbon and nitrogen consumption to a kinetic model of first degree proposed for the degradation of DOM released by Microcystis (Moreira et al., 2011). DOM degradation was assumed to happen according to three competitive processes. Adjusts and coefficient determinations were made by non-linear regressions, using the iterative algorithm from Levenberg-Marquardt (Press et al., 1992).

\subsection{Bacterial community composition}

\subsubsection{Sample preparation}

Samples of $50 \mathrm{~mL}$ from each of the replicates on the days 1, 3, 5, 9 and 15 were centrifuged at $15500 \mathrm{xg}$ for $25 \mathrm{~min}$. After, the bacterial cells were suspended in approximately $1 \mathrm{~mL}$ of sterile water, centrifuged again for $25 \mathrm{~min}$ at $15500 \mathrm{xg}$ and the pellet was maintained at $-20^{\circ} \mathrm{C}$ until extraction.

\subsubsection{DNA extraction and amplification}

DNA extraction was performed as described by Bagatini et al (2014). We performed amplifications of partial 16S rRNA gene (V6-V8 regions), by Polymerase Chain Reaction (PCR) applying primers $968 f$ with CG clamp and $1401 r$, for the Bacteria domain (Heuer et al., 1997).

\subsubsection{DGGE (Denaturing Gradient Gel \\ Electrophoresis)}

The amplified DNA was separated by electrophoresis in polyacrylamide $6 \%$ gel (acrylamide:bisacrylamide $37.5: 1$ ) with denaturing gradient (DGGE) (DCode System, Biorad). The gradient used was 35 to $60 \%$ (100\% of denaturing was defined as $7 \mathrm{M}$ urea and $40 \%[\mathrm{v} / \mathrm{v}]$ deionized formamide) and the electrophoresis was performed at $65^{\circ} \mathrm{C}$ for 15 hours at $60 \mathrm{~V}$ in TAE buffer $1 \mathrm{x}$. After electrophoresis, the gel was stained for 1 hour with GelRed solution (Biotium) in ultrapure water $(0.15 \mu \mathrm{L} / \mathrm{mL})$ for photographic documentation on a Gel Doc XR+ (BIO-RAD). The image was treated with QuantityOne software (BIO-RAD).

\subsubsection{Sequencing and statistical analysis}

After image analysis, bands were excised from the gel with sterile blade, eluted with $20 \mu \mathrm{L}$ of nanopure water at $4{ }^{\circ} \mathrm{C}$ overnight, and then amplified with the same primers (without the CG clamp in the forward primer) (Maintinguer et al., 2008). The following program of amplification was performed: initial denaturation at $94^{\circ} \mathrm{C}$ for 5 minutes; 35 cycles at $94^{\circ} \mathrm{C}$ for 1 minute, $49^{\circ} \mathrm{C}$ for 1 minute and $72^{\circ} \mathrm{C}$ for 2 minutes; final extension at $72^{\circ} \mathrm{C}$ for 5 minutes. After amplification, the DNA was precipitated with equal volume of $20 \%$ PEG 8000 (Polyethyleneglycol) and $1 \mathrm{M} \mathrm{NaCl}$ solution (Lis and Schleif, 1975) and washed twice with $125 \mu \mathrm{L}$ of $80 \%$ ethanol for purification.

The purified material was sequenced bidirectionally at Macrogen, Inc (Korea). Only the fragments with Quality Value higher than 20 (QV 20 corresponds to 99\% accuracy) were used for further analyses. The forward and reverse complement fragments were aligned with BioEdit software, version 7.1.3.0 (Hall, 1999) and a consensus sequence was obtained for each sequenced band. All consensus sequences with more than $200 \mathrm{bp}$ were checked for pairwise similarity. Sequences with identity match higher than 97\% (Stackebrandt and Goebel, 1994) were grouped and another consensus sequence was obtained and used as OTU (Operational Taxonomic Unit). The consensus sequence of each OTU was deposited in the GenBank (access numbers KJ830962 to KJ830974) and utilized for the identification of the OTUs against the sequences with good quality and longer than $1200 \mathrm{bp}$ in the Ribosomal Database Project II (RDP II - http://rdp.cme. msu.edu - (Cole et al., 2009)). The classification of the OTUs in Classes was also verified using the "classifier" facility in the RDP II (Wang et al., 2007).

\section{Results}

\subsection{Kinetics of the bacterial degradation of DOM released by $P$. agardhii}

The DOM released by $P$. agardhii had a total amount of $20.907 \pm 2.336 \mathrm{mg} . \mathrm{L}^{-1}$ (average $\pm \mathrm{SD}, \mathrm{n}=3$ ) of organic carbon and $2.003 \pm 0.242 \mathrm{mg} . \mathrm{L}^{-1}$ (average $\pm \mathrm{SD}, \mathrm{n}=3$ ) of dissolved organic nitrogen.

DOC degradation (Figure 1) showed a decay coefficient $\left(\mathrm{k}_{\mathrm{T}}\right)$ of 0.62 day $^{-1}$, with half-life $\left(\mathrm{t}^{1} / 2\right)$ of 1.12 days (Table 1). The theoretical value for the refractory fraction DOC $_{R}$ was $7.11 \mathrm{mg} . \mathrm{L}^{-1}(\approx 37.4 \%)$ and the mineralization coefficient $\left(\mathrm{k}_{3}\right)$ for this was 0.014 day $^{-1}\left(\mathrm{t}^{1 / 2}=49\right.$ days). The maximum estimated value for POC was $11.9 \mathrm{mg} \mathrm{L}^{-1}$, and its mineralization coefficient $\left(\mathrm{k}_{5}\right)$ was 0.477 day $^{-1}$ $\left(\mathrm{t}^{1 / 2}=1.45\right.$ days $)$.

The pattern for degradation of the DON (Figure 1) was similar to the observed for DOC; however, the coefficients calculated were different. The first phase had a decay coefficient of 1.5 day $^{-1}$, with half-life of 0.46 day. The second, and slower, phase had a coefficient of 0.10 day-1, increasing the half-life of compounds to 6.78 days. Coefficients for the different stages of degradation, as well as half-life, assimilation and degradation efficiency are shown in Table 1. 


\subsection{Bacterial community during degradation}

The band pattern of the DGGE gel showed the succession process in the bacterial community, with clear differences when comparing different days of degradation (Figure 2). The richness in bacterial community (number of bands in the DGGE gel) increased during the last days of degradation, although the lowest diversity was found at the fifth day, when a decrease in bacterial density and the lowest particulate $\mathrm{C}$ and $\mathrm{N}$ concentrations (Figure 1) were observed.
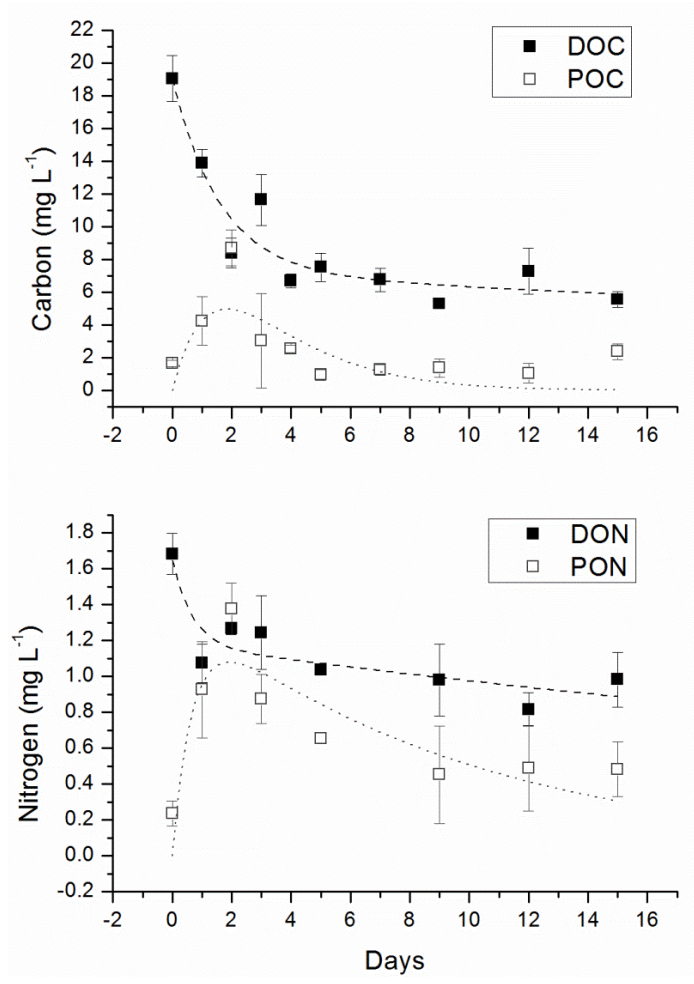

Figure 1. Decay curves of the dissolved organic carbon (DOC), incorporation and decay of particulate organic carbon (COP), decay curve of dissolved organic nitrogen (DON), incorporation and decay of particulate organic nitrogen (PON), and their respective kinetic adjustments. Error bars correspond to standard deviation, $n=3$.
After sequencing, we found that bands excised from the same height line in the DGGE had sequence similarity higher than $97 \%$ and, therefore, were considered as the same OTU (same number on Figure 2). The OTUs were assigned to the classes Alphaproteobacteria (8 OTUs), Betaproteobacteria (2 OTUs) and Gammaproteobacteria (3 OTUs) (Table 2). The OTU 01, assigned to the genus Acinetobacter (Table 2), was the only one that certainly occurred during the entire process of degradation. The strains 06 and 12 (assigned to the genera Caulobacter and Rhizobium) might also have appeared during the whole experiment, as bands of the same height were observed in all samplings, but were not sequenced for further confirmation. The OTUs $02,05,08$, 09, 10, 12 (respectively assigned to the genera Vogesella, Acidovorax, Shinella, Aeromonas and Rhizobium) were detected before the fifth day of degradation, while the OTUs 03 (unidentified Alphaproteobacteria), 13 (unidentified Rhodospirillales), 07 (possibly genus Microvirga), 04 (assigned to the order Legionellales) and 11 (assigned to the family Sphingomonadaceae, possibly Novosphingobium) were found in the $9^{\text {th }}$ and $15^{\text {th }}$ days.

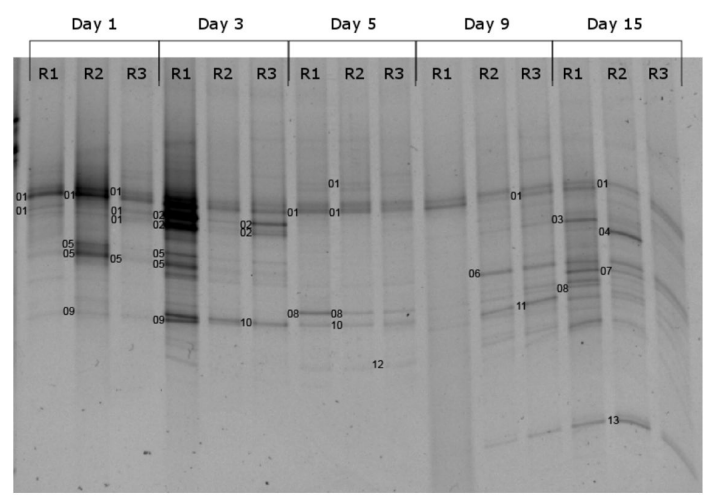

Figure 2. Molecular community profiles on DGGE showing the position of the bands excised and amplified for sequencing. The numbers are located directly to the left of the excised band sent for sequencing. Bands with similar numbers had similar sequences ( $>97 \%$ similarity) and were, therefore, considered as the same OTU.

Table 1. Summary of kinetic model parameters for the dissolved organic carbon and nitrogen degradation, in experimental cultures with DOM from $P$. agardhii.

\begin{tabular}{|c|c|c|c|c|c|c|c|c|c|c|c|}
\hline & $\begin{array}{l}{[\mathrm{DOM}]_{\mathrm{i}}} \\
\left(\mathrm{mg}^{\left.-L^{-1}\right)}\right.\end{array}$ & $\begin{array}{c}\mathbf{k}_{\mathrm{T}}^{*} \\
\left(\text { days }^{-1}\right)\end{array}$ & $\begin{array}{c}t_{1 / 2} \\
\text { (days) }\end{array}$ & $\begin{array}{c}\mathrm{DOM}_{\mathrm{R}} \\
(\%)\end{array}$ & $\begin{array}{c}k_{3}{ }^{*} \\
\left(\text { days }^{-1}\right)\end{array}$ & $\begin{array}{c}t_{1 / 2} \\
(\text { days })\end{array}$ & $\mathbf{r}^{2}$ & $\begin{array}{c}\text { POM } \\
(\%)\end{array}$ & $\begin{array}{c}k_{5}{ }^{*} \\
\left(\text { days }^{-1}\right)\end{array}$ & $\begin{array}{c}t_{1 / 2} \\
\text { (days) }\end{array}$ & $\mathbf{r}^{2}$ \\
\hline $\mathrm{DOC}_{\mathrm{Av}}$ & 19.034 & 0.62 & 1.12 & 37.4 & 0.01413 & 49 & 0.09049 & 62.5 & 0.47722 & 1.45 & 0.42482 \\
\hline $\mathrm{DON}_{\mathrm{Av}}$ & 1.65 & 1.5 & 0.46 & 70 & 0.019 & 36 & 0.81869 & $79^{\dagger}$ & $0.10211^{\dagger}$ & $6.78^{\dagger}$ & $0.72034^{\dagger}$ \\
\hline
\end{tabular}

$[\mathrm{DOM}]_{\mathrm{i}}=$ initial concentration of available organic carbon or nitrogen; $\mathrm{DOM}_{\mathrm{R}}=$ residual carbon or nitrogen; POM $=$ particulate bacterial organic carbon or nitrogen; $\mathrm{k}_{\mathrm{T}}=$ decay coefficient of DOM; $\mathrm{k}_{3}=$ mineralization coefficient of $\mathrm{DOM}_{\mathrm{R}} ; \mathrm{k} 5=$ mineralization coefficient of POM; $\mathrm{t}_{1 / 2}=$ half-life time; $\mathrm{R}^{2}=$ determination coefficient. *Parameters obtained according to the kinetics model, described in Material and Methods; The kinetics model presented an uncoupling in the assimilation and degradation of nitrogen, as discussed in the text. 


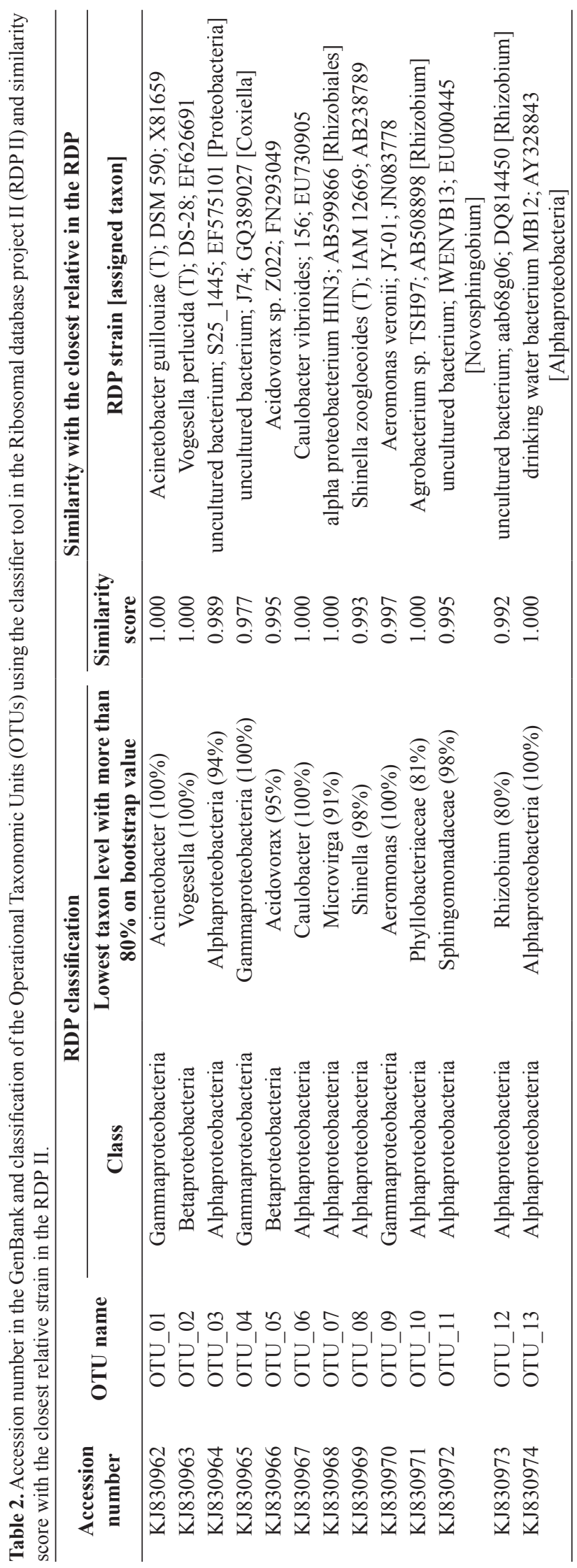




\section{Discussion}

\subsection{Degradation kinetics of dissolved organic carbon and nitrogen}

The degradation process of $P$. agardhii DOM presented two distinct phases. The first phase occurred during the first 5 days with a fast decay of the available DOC (Table 1, Figure 1). The consumption of a large quantity of phytoplankton-originated DOC within the first days of experiment demonstrated its high availability to bacterial utilization. Similar patterns of degradation, with a rapid phase followed by a slower step where also analyzed in experiments by Chen and Wangersky (1996) and Moreira et al. (2011).

The kinetics model also found a high efficiency in the process of incorporation of organic carbon to bacterial biomass, reaching $62.5 \%$ of the available DOC. However, considering the sampling periods, the mineralization of the more labile fraction could not be completely observed experimentally, which could explain the appearance of a theoretically higher productivity than the observed production of bacterial biomass (particulate organic carbon - POC). Previous studies also showed a high efficiency, ranging from $44-100 \%$ of the DOC released by phytoplankton incorporated by the bacterial community in short-time experiments (Feuillade et al., 1988; Jensen, 1983). It is known that up to $30 \%$ of the photosynthetically fixed carbon is released as DOC in the environment and it can constitute substrate and energy source to heterotrophic organisms, mainly bacteria (Feuillade et al., 1988). Also, the microbial degradation may be the cause of variation in the availability of nitrogen, phosphorus and inorganic carbon, directly affecting the growth of autotrophic or heterotrophic organisms (Klug, 2005).

Although carbohydrates are the most prominent substances among extracellular products released by phytoplankton, proteins and amino acids are also important fractions of DOM, together with a variety of other compounds (Myklestad, 2000). These compounds may represent a necessary source of nitrogen to bacterial and phytoplankton communities, as it was already described the ability of bacterial isolates to consume and grow with amino acids and protein as the only nitrogen source (Ietswaart et al., 1994). The source of nitrogen and its availability are also known to have a selective effect on the bacterial groups (Bell, 1984). The degradation of DON in our experiments followed a similar pattern to the one found to DOC, although with higher rates of decay. However, the percentage of residual DON was larger than carbon, reaching around $70 \%$ of the total available initially. The exact process of decomposition/uptake of nitrogen in this experiment could not be completely predicted by the model applied, probably due to the fast turnover within different bacterial populations: the compounds were released by one group and swiftly captured by another in periods shorter than the sampling intervals, causing the uncoupling between equations (Table 1).
Working with an axenic culture allowed the study of the whole process of degradation of phytoplankton released DOM, simulating the release of material by these cyanobacteria in a reservoir and its utilization by the bacterial heterotrophic community as the utilization of co-cultures of phytoplankton/bacteria can make subtle changes in the released organic matter composition (Bruckner et al., 2011). However, in a reservoir, it should also be considered the continuous and diverse range of sources of carbon and nitrogen available, either autochthonous or allochthonous (Dellamano-Oliveira et al., 2007; Tundisi et al., 2008), which can provide the permanent availability of compounds.

A representative quantity of residual carbon was found in the experimental cultures (37.4\%). Although the high availability of phytoplankton-originated DOC it can still be accumulated during blooms of freshwater phytoplankton, creating a pool of residual DOC (Kragh and Søndergaard, 2004). Different compounds, like polysaccharides, might be more or less degradable by bacteria (Giroldo et al., 2007), requiring specific adaptations for its success and even the degradation itself might result in more refractory compounds (Bittar et al., 2015). However, this residual DOC still have a appreciable return to the pelagic food web via bacterial consumption (Coveney and Wetzel, 1989), although at a slower pace, and thus, assuming an considerable ecological role.

The kinetics of the bacterial degradation/uptake of $P$. agardhii-originated DOM suggests the labile nature of the DOM, and when compared to the retention time of the reservoir, could indicate minimal loss of DOM from this environment, either by sinking to the bottom or exportation downstream. Furthermore, the elucidation of this process helped to demonstrate the ecological importance of this Cyanobacteria and its related bacterial community to the nutrient availability and nutrient cycling in this environment.

\subsection{Dynamics of bacterial community}

The release of phytoplankton-originated DOM in the environment affects bacterial growth and the bacterial community composition, changing the availability of different compounds and, therefore, the growth of many autotrophs and heterotrophs (Klug, 2005). In turn, the DOM composition may also have determinant importance in the taxonomic composition of the bacterioplankton community, including its variation along the degradation process (Puddu et al., 2003).

The presence of residual compounds and reduction in nutrient availability during the second phase of degradation might have been an important factor in the determination of the bacterial community composition. Analysis of the DGGE gel (Figure 2) showed evident differences in band patterns between those sampling days.

Richness, here analyzed as the number of bands in the DGGE gel (Riemann et al., 1999), decreased in the $5^{\text {th }}$ day of degradation (Figure 2), which could represent a response to the changes in the community related to the reduced availability of nutrients and the modified substrate. The appearance of new bands during 
the later phase of degradation, was probably reflecting slow-growing species that did not reach detectable quantities previously or represent a succession process caused by complex interactions, such as the utilization of secondary compounds excreted by other bacteria as food source (Langenheder et al., 2004), or opportunistic utilization of products degraded by other bacteria. Janse et al. (2000), in a study with Phaeocystis, found that only after the degradation of mucopolysaccharides ceased there was a clear increase in band diversity. Also, Langenheder et al. (2004) showed an increase on bacterial richness by DGGE profile in batch cultures during the stationary growth phase of the bacteria. Different bands representing the same OTU in DGGE gel (Figure 2) may be due to ambiguities in the sequences (Verleyen et al., 2010), since differences less than $0.6 \%$ may result in different bands (Bondoso et al., 2014 ) and we defined OTUs at $97 \%$ identity threshold.

Further evidence of the changes in the bacterial community during the degradation of the organic compounds released by $P$. agardhii was found after sequencing of selected samples. The only sequenced genus found during the whole experiment, Acinetobacter, has acknowledged versatility, growing in different sources and concentrations of organic carbon and nitrogen, including poor environments (Baumann et al., 1968; Henriksen, 1973).

Organisms of the class Alphaproteobacteria, order Rhizobiales (represented by the genera Caulobacter, Shinella, and possibly Novosphingobium) were found mainly during the slower phase of degradation, when nutrient availability consisted only in more refractory compounds at limiting amounts, reflecting the group usual dominance in oligotrophic systems (Barlett and Leff, 2010). Bagatini et al. (2014) also found increasing proportions of Alphaproteobacteria associated with two Cyanobacteria along cultivation time and the genus Novosphingobium has already been associated with high concentrations of recalcitrant compounds (Kent et al., 2006).

The Betaproteobacteria, on the other hand, are a dominant group in a wide variety of aquatic environments (Liu et al., 2012; Newton et al., 2006; Šimek et al., 2005) and thus, bands representing this group were found during the whole experiment, although dominated only in the first days of degradation, together with Gammaproteobacteria. The large distribution of Betaproteobacteria in freshwater environments is usually associated to their high capacity of adaptation to different environments, and fast response of growth (Burkert et al., 2003; Šimek et al., 2005). Langenheder et al. (2004) suggested that Gammaproteobacteria may be fast growing opportunists dominating at high nutrient levels, whereas in low nutrient concentrations they may be out-competed by Alphaproteobacteria.

The availability of nutrients, as the carbon and nitrogen sources, play a major part in the selection of the heterotrophic bacterial community which will be established in an environment (Allen et al., 2005; Davidson et al., 2007). Thus, as analyzed in this study, variations in the composition of the DOM released by P. agardhii during degradation process were coupled changes in the bacterial concentration and composition, with the selection of more or less specialized groups. As P. agardhii blooms are frequent events in reservoirs, the organic matter released by these organisms are a constant source of substrate and might, therefore, be an important factor in selecting the bacterial community in this environment and providing a considerable amount of labile organic carbon for the food web through the microbial loop.

\section{Acknowledgements}

We thank Fundação de Amparo à Pesquisa do Estado de São Paulo (FAPESP) and Conselho Nacional de Desenvolvimento Científico e Tecnológico (CNPq) for financial support and grants. We are also grateful to Nelma R. Segnini Bossolan and Julia Mara Martins from Physics Institute of São Carlos (University of São Paulo) for allowing us to use the DCode System of Biorad for the DGGE, and for technical assistance.

\section{References}

ALLEN, A.E., BOOTH, M.G., VERITY, P.G. and FRISCHER, M.E., 2005. Influence of nitrate availability on the distribution and abundance of heterotrophic bacterial nitrate assimilation genes in the Barents Sea during summer. Aquatic Microbial Ecology, vol. 39, no. 3, pp. 247-255. http://dx.doi.org/10.3354/ame039247.

AZAM, F., SMITH, D.C., STEWARD, G.F. and HAGSTRÖM, $\AA$ A., 1994. Bacteria-organic matter coupling and its significance for oceanic carbon cycling. Microbial Ecology, vol. 28, no. 2, pp. 167-179. http://dx.doi.org/10.1007/BF00166806.

BAGATINI, I.L., EILER, A., BERTILSSON, S., KLAVENESS, D., TESSAROLLI, L.P. and VIEIRA, A.A.H., 2014. Host-specificity and dynamics in bacterial communities associated with bloomforming freshwater phytoplankton. PLoS One, vol. 9, no. 1, pp. e85950. http://dx.doi.org/10.1371/journal.pone.0085950.

BARLETT, M.A. and LEFF, L.G., 2010. The effects of N: P ratio and nitrogen form on four major freshwater bacterial taxa in biofilms. Canadian Journal of Microbiology, vol. 56, no. 1, pp. 32-43. http://dx.doi.org/10.1139/W09-099.

BAUMANN, P. and DOUDOROFF, M. and STANIER R.Y., 1968. A study of the Moraxella group II. Oxidative-negative species (genus Acinetobacter). Journal of Bacteriology, vol. 95, no. 5 , pp. $1520-1541$.

BELL, W.H., 1984. Bacterial adaptation to low-nutrient conditions as studied with algal extracellular products. Microbial Ecology, vol. 10, no. 3, pp. 217-230. http://dx.doi.org/10.1007/BF02010936.

BITTAR, T.B., VIEIRA, A.A.H., STUBBINS, A. and MOPPER, K., 2015. Competition between photochemical and biological degradation of dissolved organic matter from the cyanobacteria Microcystis aeruginosa. Limnology and Oceanography, vol. 60, no. 4, pp. 1172-1194. http://dx.doi.org/10.1002/lno.10090.

BONDOSO, J., BALAGUÉ, V., GASOL, J.M. and LAGE, O.M., 2014. Community composition of the Planctomycetes associated with different macroalgae. FEMS Microbiology Ecology, vol. 88, no. 3, pp. 445-456. http://dx.doi.org/10.1111/1574-6941.12258.

BONILLA, S., AUBRIOT, L., SOARES, M.C.S., GONZÁLEZPIANA, M., FABRE, A., HUSZAR, V.L.M., LÜRLING, M., 
ANTONIADES, D., PADISÁK, J. and KRUK, C., 2012. What drives the distribution of the bloom-forming cyanobacteria Planktothrix agardhii and Cylindrospermopsis raciborskii? FEMS Microbiology Ecology, vol. 79, no. 3, pp. 594-607. http://dx.doi. org/10.1111/j.1574-6941.2011.01242.x.

BRIAND, E., GUGGER, M., FRANÇOIS, J.-C., BERNARD, C., HUMBERT, J.-F. and QUIBLIER, C., 2008. Temporal variations in the dynamics of potentially microcystin-producing strains in a bloom-forming Planktothrix agardhii (cyanobacterium) population. Applied and Environmental Microbiology, vol. 74, no. 12, pp. 3839-3848. http://dx.doi.org/10.1128/AEM.02343-07.

BRUCKNER, C.G., REHM, C., GROSSART, H.-P. and KROTH, P.G., 2011. Growth and release of extracellular organic compounds by benthic diatoms depend on interactions with bacteria. Environmental Microbiology, vol. 13, no. 4, pp. 1052-1063. http:// dx.doi.org/10.1111/j.1462-2920.2010.02411.x.

BURKERT, U., WARNECKE, F., BABENZIEN, D., ZWIRNMANN, E. and PERNTHALER, J., 2003. Members of a readily enriched $\beta$-proteobacterial clade are common in surface waters of a humic lake. Applied and Environmental Microbiology, vol. 69, no. 11, pp. 6550-6559. http://dx.doi.org/10.1128/AEM.69.11.6550-6559.2003.

CHEN, W. and WANGERSKY, P.J., 1996. Rates of microbial degradation of dissolved organic carbon from phytoplankton cultures. Journal of Plankton Research, vol. 18, no. 9, pp. 15211533. http://dx.doi.org/10.1093/plankt/18.9.1521.

CHEN, W., SONG, L., PENG, L., WAN, N., ZHANG, X. and GAN, N., 2008. Reduction in microcystin concentrations in large and shallow lakes: water and sediment-interface contributions. Water Research, vol. 42, no. 3, pp. 763-773. http://dx.doi.org/10.1016/j. watres.2007.08.007.

COLE, J.R., WANG, Q., CARDENAS, E., FISH, J., CHAI, B., FARRIS, R.J., KULAM-SYED-MOHIDEEN, A.S., MCGARRELL, D.M., MARSH, T., GARRITY, G.M. and TIEDJE, J.M., 2009. The Ribosomal Database Project: improved alignments and new tools for rRNA analysis. Nucleic Acids Research, vol. 37, suppl. 1, pp. D141-D145. http://dx.doi.org/10.1093/nar/gkn879.

COVENEY, M.F. and WETZEL, R.G., 1989. Bacterial metabolism of algal extracellular carbon. Hydrobiologia, vol. 173, no. 2, pp. 141-149. http://dx.doi.org/10.1007/BF00015524.

DAVIDSON, K., GILPIN, L.C., HART, M.C., FOUILLAND, E., MITCHELL, E., Á LVAREZ CALLEJA, I., LAURENT, C.É., MILLER, A.E.J. and LEAKEY, R.J.G., 2007. The influence of the balance of inorganic and organic nitrogen on the trophic dynamics of microbial food webs. Limnology and Oceanography, vol. 52, no. 5, pp. 2147-2163. http://dx.doi.org/10.4319/lo.2007.52.5.2147.

DELLAMANO-OLIVEIRA, M.J., COLOMBO-CORBI, V. and VIEIRA, A.A.H., 2007. Dissolved carbohydrates from Barra Bonita Reservoir (São Paulo State, Brazil) and its relationships with phytoplanktonic abundant algae. Biota Neotropica, vol. 7, no. 2, pp. 59-66.

FEUILLADE, M., DUFOUR, P. AND FEUILLADE, J. 1988. Organic carbon release by phytoplankton and bacterial reassimilation. Swiss journal of hydrology, vol. 50, no. 2, pp. 115-135.

GIROLDO, D., ORTOLANO, P.I.C. and VIEIRA, A.A.H., 2007. Bacteria-algae association in batch cultures of phytoplankton from a tropical reservoir: the significance of algal carbohydrates. Freshwater Biology, vol. 52, no. 7, pp. 1281-1289. http://dx.doi. org/10.1111/j.1365-2427.2007.01764.x.
GORHAM, P.R., MCLACHLAN, J. HAMMER, U.T., 1964. and KIM, W.K. Isolation and culture of toxic strains of Anabaena flosaquae (Lyngb) de Bréb. International Association of Theorethical and Applied Limnology, vol. 15, pp. 796-804.

HALL, T. A., 1999. BioEdit: a user-friendly biological sequence alignment editor and analysis program for Windows 95/98/NT. Nucleic Acids Symposium Series, vol. 41, pp. 95-98.

HENRIKSEN, S.D., 1973. Moraxella, Acinetobacter, and the Mimeae. Bacteriological Reviews, vol. 37, no. 4, pp. 522-561.

HEUER, H., KRSEK, M., BAKER, P. and SMALLA, K., 1997. Analysis of actinomycete communities by specific amplification of genes encoding 16S rRNA and gel-electrophoretic separation in denaturing gradients. Applied and Environmental Microbiology, vol. 63 , no. 8 , pp. 3233-3241.

HO, L., TANG, T., MONIS, P.T. and HOEFEL, D., 2012. Biodegradation of multiple cyanobacterial metabolites in drinking water supplies. Chemosphere, vol. 87, no. 10, pp. 1149-1154. http://dx.doi.org/10.1016/j.chemosphere.2012.02.020.

IETSWAART, T., SCHNEIDER, P.J. and PRINS, R.A., 1994. Utilization of organic nitrogen sources by two phytoplankton species and a bacterial isolate in pure and mixed cultures. Applied and Environmental Microbiology, vol. 60, no. 5, pp. 1554-1560.

JANSE, I., ZWART, G., VAN DER MAAREL, M.J.E.C. and GOTTSCHAL, J.C., 2000. Composition of the bacterial community degrading Phaeocystis mucopolysaccharides in enrichment cultures. Aquatic Microbial Ecology, vol. 22, no. 2, pp. 119-133. http:// dx.doi.org/10.3354/ame022119.

JENSEN, L.M., 1983. Phytoplankton release of extracellular organic carbon, molecular weight composition, and bacterial assimilation. Marine ecology progress series. Oldendorf, vol. 11, no. 1, pp. 39-48. http://dx.doi.org/10.3354/meps011039.

JONES, S.E., NEWTON, R.J. and MCMAHON, K.D., 2009. Evidence for structuring of bacterial community composition by organic carbon source in temperate lakes. Environmental Microbiology, vol. 11, no. 9, pp. 2463-2472. http://dx.doi. org/10.1111/j.1462-2920.2009.01977.x.

KENT, A.D., JONES, S.E., LAUSTER, G.H., GRAHAM, J.M., NEWTON, R.J. and MCMAHON, K.D., 2006. Experimental manipulations of microbial food web interactions in a humic lake: shifting biological drivers of bacterial community structure. Environmental Microbiology, vol. 8, no. 8, pp. 1448-1459. http:// dx.doi.org/10.1111/j.1462-2920.2006.01039.x.

KLUG, J.L., 2005. Bacterial response to dissolved organic matter affects resource availability for algae. Canadian Journal of Fisheries and Aquatic Sciences, vol. 62, no. 2, pp. 472-481. http://dx.doi.org/10.1139/f04-229.

KOKOCIŃSKI, M., STEFANIAK, K., MANKIEWICZ-BOCZEK, J., IZYDORCZYK, K. and SOININEN, J., 2010. The ecology of the invasive cyanobacterium Cylindrospermopsis raciborskii (Nostocales, Cyanophyta) in two hypereutrophic lakes dominated by Planktothrix agardhii (Oscillatoriales, Cyanophyta). European Journal of Phycology, vol. 45, no. 4, pp. 365-374. http://dx.doi. org/10.1080/09670262.2010.492916.

KORMAS, K.A. and LYMPEROPOULOU, D.S., 2013. Cyanobacterial toxin degrading bacteria: who are they? BioMed research international, vol. 2013, no. 463894, pp. 01-12.

KRAGH, T. and SøNDERGAARD, M., 2004. Production and bioavailability of autochthonous dissolved organic carbon: effects 
of mesozooplankton. Aquatic Microbial Ecology, vol. 36, no. 1, pp. 61-72. http://dx.doi.org/10.3354/ame036061.

LANGENHEDER, S., KISAND, V., LINDSTRÖM, E.S., WIKNER, J. and TRANVIK, L.J., 2004. Growth dynamics within bacterial communities in riverine and estuarine batch cultures. Aquatic Microbial Ecology, vol. 37, no. 2, pp. 137-148. http://dx.doi. org/10.3354/ame037137.

LIS, J.T. and SCHLEIF, R., 1975. Size fractionation of doublestranded DNA by precipitation with polyethylene glycol. Nucleic Acids Research, vol. 2, no. 3, pp. 383-390. http://dx.doi. org/10.1093/nar/2.3.383.

LIU, Z., HUANG, S., SUN, G., XU, Z. and XU, M., 2012. Phylogenetic diversity, composition and distribution of bacterioplankton community in the Dongjiang River, China. FEMS Microbiology Ecology, vol. 80, no. 1, pp. 30-44. http:// dx.doi.org/10.1111/j.1574-6941.2011.01268.x.

MACKERETH, F.J.H., HERON, J. and TALLING, J.F., 1978. Water analysis: some revised methods for limnologists. Kendall: Titus Wilson and Son Ltd. Freshwater Biological Association Scientific Publication, no. 36.

MAINTINGUER, S.I., FERNANDES, B.S., DUARTE, I., SAAVEDRA, N.K., ADORNO, M. and VARESCHE, M., 2008. Fermentative hydrogen production by microbial consortium. International Journal of Hydrogen Energy, vol. 33, no. 16, pp. 4309-4317. http://dx.doi.org/10.1016/j.ijhydene.2008.06.053.

MATSUMURA-TUNDISI, T. and TUNDISI, J.G., 2005. Plankton richness in a eutrophic reservoir (Barra Bonita Reservoir, SP, Brazil). Hydrobiologia, vol. 542, no. 1, pp. 367-378. http://dx.doi. org/10.1007/s10750-004-9461-0.

MOREIRA, I.C., BIANCHINI JUNIOR, I. and VIEIRA, A.A.H., 2011. Decomposition of dissolved organic matter released by an isolate of Microcystis aeruginosa and morphological profile of the associated bacterial community. Brazilian Journal of Biology $=$ Revista Brasileira de Biologia, vol. 71, no. 1, pp. 57-63. http:// dx.doi.org/10.1590/S1519-69842011000100009.

MYKLESTAD, S., HOLM-HANSEN, O., VÅRUM, K.M. and VOLCANI, B.E., 1989. Rate of release of extracellular amino acids and carbohydrates from the marine diatom Chaetoceros affinis. Journal of Plankton Research, vol. 11, no. 4, pp. 763-773. http://dx.doi.org/10.1093/plankt/11.4.763.

MYKLESTAD, S.M., 2000. Dissolved organic carbon from phytoplankton. In: P.J. WANGERSKY, Marine Chemistry. Heidelberg: Springer Berlin Heidelberg, pp. 111-148. The Handbook of Environmental Chemistry, no. 5.

NEWTON, R.J., KENT, A.D., TRIPLETT, E.W. and MCMAHON, K.D., 2006. Microbial community dynamics in a humic lake: differential persistence of common freshwater phylotypes. Environmental Microbiology, vol. 8, no. 6, pp. 956-970. http:// dx.doi.org/10.1111/j.1462-2920.2005.00979.x.

OBERHAUS, L., BRIAND, J.F., LEBOULANGER, C., JACQUET, S. and HUMBERT, J.F., 2007. Comparative effects of the quality and quantity of light and temperature on the growth of Planktothrix agardhii and P. rubescens1. Journal of Phycology, vol. 43, no. 6, pp. 1191-1199. http://dx.doi.org/10.1111/j.1529-8817.2007.00414.x.

PRESS, W.H., TEUKOLSKY, S.A., VETTERLING, W.T. and FLANNERY, B.P., 1992. Numerical recipes in C: the art of scientific computing. New York: Cambridge University Press. 994 p.
PUDDU, A., ZOPPINI, A., FAZI, S., ROSATI, M., AMALFITANO, S. and MAGALETTI, E., 2003. Bacterial uptake of DOM released from P-limited phytoplankton. FEMS Microbiology Ecology, vol. 46, no. 3, pp. 257-268. http://dx.doi.org/10.1016/S01686496(03)00197-1.

RIEMANN, L., F. STEWARD, G., FANDINO, L.B., CAMPBELL, L., LANDRY, M.R. and AZAM, F., 1999. Bacterial community composition during two consecutive NE Monsoon periods in the Arabian Sea studied by denaturing gradient gel electrophoresis (DGGE) of rRNA genes. Deep-sea Research. Part II, Topical Studies in Oceanography, vol. 46, no. 8-9, pp. 1791-1811

SARMENTO, H. and GASOL, J.M., 2012. Use of phytoplanktonderived dissolved organic carbon by different types of bacterioplankton. Environmental Microbiology, vol. 14, no. 9, pp. 2348-2360. http:// dx.doi.org/10.1111/j.1462-2920.2012.02787.x.

ŠIMEK, K., HORŇÁK, K., JEZBERA, J., MAŠÍN, M., NEDOMA, J., GASOL, J.M. and SCHAUER, M., 2005. Influence of topdown and bottom-up manipulations on the R-BT065 subcluster of $\beta$-Proteobacteria, an abundant group in bacterioplankton of a freshwater reservoir. Applied and Environmental Microbiology, vol. 71, no. 5, pp. 2381-2390. http://dx.doi.org/10.1128/ AEM.71.5.2381-2390.2005.

SOLÓRZANO, L., 1969. Determination of Ammonia in Natural Waters by the Phenolhypochlorite Method. Limnology and Oceanography, vol. 14, no. 5, pp. 799-801.

STACKEBRANDT, E. and GOEBEL, B.M., 1994. Taxonomic note: a place for DNA-DNA reassociation and $16 \mathrm{~S}$ rRNA sequence analysis in the present species definition in bacteriology. International Journal of Systematic Bacteriology, vol. 44, no. 4, pp. 846-849.

THOMAS, J.D., 1997. The role of dissolved organic matter, particularly free amino acids and humic substances, in freshwater ecosystems. Freshwater Biology, vol. 38, no. 1, pp. 1-36. http:// dx.doi.org/10.1046/j.1365-2427.1997.00206.x.

TONK, L., VISSER, P.M., CHRISTIANSEN, G., DITTMANN, E., SNELDER, E.O.F.M., WIEDNER, C., MUR, L.R. and HUISMAN, J., 2005. The microcystin composition of the cyanobacterium Planktothrix agardhii changes toward a more toxic variant with increasing light intensity. Applied and Environmental Microbiology, vol. 71, no. 9, pp. 5177-5181. http://dx.doi. org/10.1128/AEM.71.9.5177-5181.2005.

TUNDISI, J.G., MATSUMURA-TUNDISI, T. and ABE, D.S., 2008. The ecological dynamics of Barra Bonita (Tietê River, SP, Brazil) reservoir: implications for its biodiversity. Brazilian Journal of Biology = Revista Brasileira de Biologia, vol. 68, no. 4, pp. 1079-1098. http://dx.doi.org/10.1590/S1519-69842008000500015.

VERLEYEN, E., SABBE, K., HODGSON, D.A., GRUBISIC, S., TATON, A., COUSIN, S., WILMOTTE, A., DE WEVER, A., VAN DER GUCHT, K. and VYVERMAN, W., 2010. Structuring effects of climate-related environmental factors on Antarctic microbial mat communities. Aquatic Microbial Ecology, vol. 59, pp. 11-24. http://dx.doi.org/10.3354/ame01378.

WANG, Q., GARRITY, G.M., TIEDJE, J.M. and COLE, J.R., 2007. Naive Bayesian classifier for rapid assignment of rRNA sequences into the new bacterial taxonomy. Applied and Environmental Microbiology, vol. 73, no. 16, pp. 5261-5267. http://dx.doi.org/10.1128/AEM.00062-07. 